\title{
Territorial bioethics: participatory design as a catalyst for social welfare in groups vulnerable to climate change
}

\author{
Bioética territorial: el diseño participativo como catalizador del bienestar social en grupos \\ vulnerables ante el cambio climático
}

Silvia L. Aguilar-Velázquez ${ }^{a}$, Karina G. Muñoz-Guadarrama, ${ }^{b}$, Lilia S. Carrillo-Medina $^{c}$

\begin{abstract}
:
The following work is an approach to the theoretical framework that builds the concept of territorial Bioethics, as part of the paradigm of urban development and the policy of attention to the spatial needs of society; It is part of the project of consolidation of the research line on indicators for urban sustainability and identifies within the process of social resilience, the relations between the territory, the anthropic environment and the attitudes of the social organization as well as models of reconstitution of environments degraded

Emphasizes the active attitude of society to promote effective and dignified intervention with participation instruments; that it manages to restore attributions of adaptation and resilience to the environmental emergency; In addition, reference is made to a group vulnerable to such an emergency: the elderly.
\end{abstract}

\section{Keywords:}

Social welfare, Environment, Vulnerability, Climate Change, Territorial Bioethics, Elderly

\section{Resumen:}

El siguiente trabajo es un acercamiento al marco teórico referencial que construye el concepto de Bioética territorial, como parte del paradigma del desarrollo urbano y la política de atención a las necesidades espaciales de la sociedad; forma parte del proyecto de consolidación de la línea de investigación sobre indicadores para la sustentabilidad urbana e identifica dentro del proceso de resiliencia social, las relaciones entre el territorio, el medio antrópico y las actitudes de la organización social así como de modelos de reconstitución de entornos degradados.

Enfatiza la actitud activa de la sociedad para promover con instrumentos de participación una intervención eficaz y dignificante; que logre restituir atribuciones de adaptación y resiliencia ante la emergencia ambiental; además, se hace referencia a un grupo vulnerable ante dicha emergencia: el adulto mayor.

\section{Palabras Clave:}

Bienestar social, Medioambiente, Vulnerabilidad, Cambio Climático, Bioética Territorial, Adulto mayor

\footnotetext{
a Autor de Correspondencia, Universidad Autónoma del Estado de Hidalgo, Instituto de Ciencias Sociales y Humanidades, Área Académica de Sociología y Demografía, Pachuca, Hidalgo, México, https://orcid.org/0000-0001-5451-3862, Email: slaguilarv2@ gmail.com

b Estudiante de la Maestría en Planeación y Desarrollo Regional del Colegio del Estado de Hidalgo, Pachuca, Hidalgo, México, Coordinadora General de la Red Iberoamericana de Estudios sobre Sociedad, Ciudad y Medioambiente, https://orcid.org/0000-003-45614156, Email: kariimo75@gmail.com

c Universidad de León, Profesor del Área de Posgrado en Arquitectura, León, Guanajuato, México, directora de la Red Iberoamericana de Estudios sobre Sociedad, Ciudad y Medioambiente, https://orcid.org/0000-0002-2241-0962, Email: red.nomadic.scm@gmail.com
} 


\section{INTRODUCTION}

This first approach building the reference framework about territorial bioethics has as objective to increase the line of research that focuses on the welfare state and dignified life. The concept of bioethics is related to as a matter of priority to the Health Sciences .According to the National Commission of Bioethics, is a branch of Applied Ethics that reflects

deliberates, promotes regulatory approaches and public policies to regulate and to solve conflicts of social life, especially in life sciences, as well as in practice and medical research that affect life on the planet not only currently but also in future generations. (CONBIOETIC Council, 2014).

It is understood the importance of reinforcing the relation between bioethics and territorial intervention due to the document: Perspectives of environment worldwide, presented to United Nations (2019) in which climate change is based as central part of environmental contingency and proposes through delegates, the determination of generating instruments to the adaptation and resilience as a model of confrontation to the climate emergency, the same is related to the current land use practices, territorial planning and urban development.

Currently, one of the most relevant topics of international community is climate change. According to United Nations (2019)" cities consume great part of the world's energy supply and they are responsible for $70 \%$ of greenhouse gas emissions". At the same time, due to their configuration as centers of development technological, innovational and creativity can give responses to combat the state of climatic emergency and impending collapse of territorial social structures as we know them nowadays, because of forced displacements of population to a massive level and restructuring of systems of consumption of resources.

\section{DEVELOPMENT}

On one side, in view of the climate emergency, it is evident the risk and the vulnerability state that society has been exposed. On the other side, it is important to observer the responsibilities that communities have on their environment in conditions of degradation. National Atlas of vulnerability to climate change (INECC, 2019) shows the projection of projected impacts of climate change in Mexico (Image1).
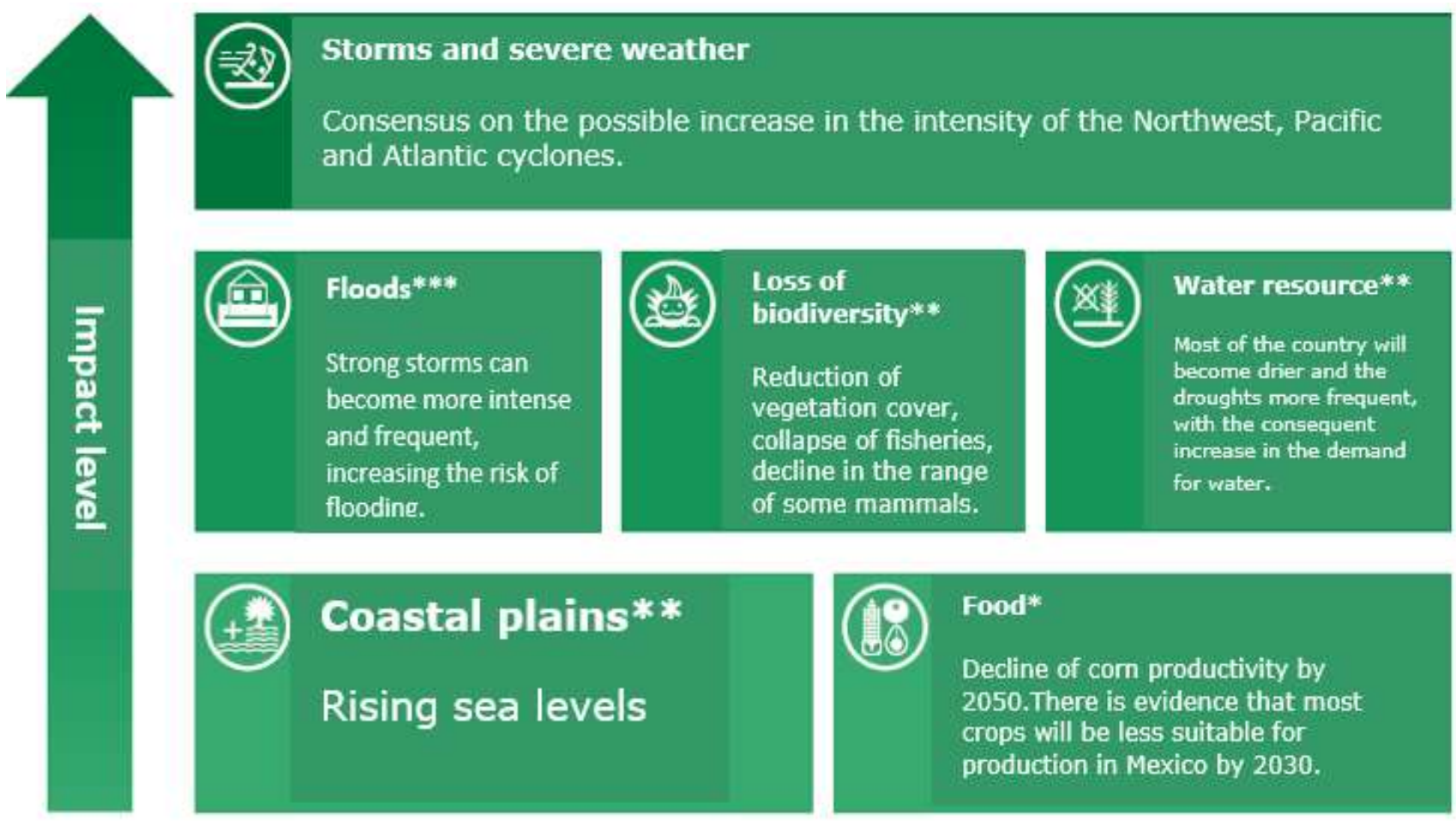

Food*

Decline of com productivity by

2050. There is evidence that most

crops will be less suitable for

production in Mexico by 2030 .

*Confidence level Adaptad from Special Climate Change Program (SCCP, 2014)

Image 2. Projected impacts of Climate change in Mexico.

Source: National Atlas of vulnerability to climate change, INECC, 2019.

It has been observed that the first feedback mechanism for climate change and environmental contingency is migration. On the basis of International Organization for Migration (IOM) poses a migration problem related to climate change defined as" migrants 
displaced by environmental factors, they are people that due to sudden changes to gradual ones in environment, they have negative life conditions and also are obligated to abandon their habitual residences in a temporal or permanent way and move to other parts from their own country or outside. (SEGOB, 2016).

In the annual report, the World Bank(2018) estimated that 2050 the number of migrants will be of more than 143 million of people in Latin American, South Asia and Sub-Saharan Africa.

Nevertheless, in the case of the elderly, the perspective of risk and vulnerability is different because it is known that if society faces an immediate response to the contingency, the possibilities of old age reduce.

Colagiuri (2014) explains that during the 21st century the movement of people was dramatically expanded due to climate change. When populations lack of resources to migration planning, the risk exposure is open and it correlates with elements as economic development, savings capacity, and migration policy that exposes migrant to the lack. PICC en 2014 (IPCC in English)considers that the more people migrate or are forced to migrate due to weather conditions, the elderly are more vulnerable and an ample evidence show that the elderly are generally in dangerous environments when the rest of the community commutes.

The prevalence of ageing population in risk centers is related to the physical welfare conditions, not being in good health and reduced mobility that prevent displacements.

Apart from the foregoing, psychosocial factors such as roots heritage and identity are welfare indicators in other territorial adjectives.

In this way, it results evident that climate change has determined a series of socio-territorial mechanisms that Msuya (Quiñones, 2019) explains that "Health and human prosperity are directly related to the condition of the environment". For all that, UN establishes an immediate action to develop those instruments that not only avoid disasters but also problems confronting society to the human and social development related to the capacity of adaptation and resilience (Mizutori, Mami. 2019).Understanding that cultural construct as an inherent element that encourages the development of a person and gives him/her identity qualities and allows him/her to foster social cohesion.

As an alternative to the risk and the instruments created that assume co-responsibility to the society to the ethics of intervention on the territory, participatory design, raises to the citizen not only as a user of the city but also as an actor or main core of study, construction and development of his/her own environment. (Di Siena, 2015). The term that is designed is of a pro-sumer citizenship that consumes ,but also produces something in its environment and takes advantage of the common of the people but at the same time brings only one part.

A rather broad definition is the one proposed by MonoDestudio (2015) on the basis of the work of Carmona y Tiesdell (2007) who define the design of the social(civic and participative) as a job of designing places to people, looking for collecting an structure of underlying social relations, not only focusing on aesthetical canons.

Domenico di Siena (Civil Design, 2016) explains that in the task about participative design that the type of projects that designer considers are based on collective intelligence,- and may differ in nature that could lead to the professional to plan a government strategy in order to build a collaborative project with citizenship which a project of regeneration of a degraded public space.

Since some years ago, some professionals related to human design are no longer designing projects or completed proposals, closed professional products and ready to be done. Instead of that, designing tools, processes, methodologies or strategies that help to resolve advancement of projects or proposals whose main objectives are beyond the reach of the individuality of professionals that develop them.

"Thus it can be raised that the participation of each organization constitutes a collective process, because each organism will define the ways in which citizens participate. As a result, when we talk about participative processes must be taken as city strategies where there is a true support to transformation and innovation, and whose objective is to diagnose the urban and territorial environment .So it is important to clarify the relation expected with the citizens and the future changes, to work together on an agenda of how cities will be taken from an integrated perspective and how future is expected, to cause management methods with territorial resources safeguarded"

(MonoDeestudio, 2015).

For all that, participatory design offers and mechanism of prevention to risk, decreases the state of vulnerability thus a social instrument faces all the participants of the territory in an integrated manner, and prioritizes the immediate necessity that society would identify.

The structure of participatory design generates a possibility to provide reference frameworks to the design of resilient territories with adaptation mechanisms and that assume attitudes of a cultural nature as transfers in favor of the development of intangibles results, as well as, heritage construction and that bring well-being opportunities in social collaboration. 
In a way that the elderly population is considered as majority or increases the presence of territories where there are not spaces that resolve their needs including daily life, the quality of anthropogenic ecosystems and the access to the services and physical infrastructure will be viewed as a matter of priority in public health and topics of land sustainability as water access, prevention to risk until inequality and health gap.

\section{Conclusion}

Climate change causes effects to large-scale effects to the population; however, the most vulnerable group is the elderly. In the case of Mexico demographic projections show that

older population will continue growing and reaching to 36.5 million in 2050. (Partida, 2005). According to Inter-censal Population Survey elaborated and applied by the National Institute of Statistics and Geography in 2015, this part of the Mexican population increases to 12.4 million.

Help Age International (2015) states that this part of the population that does not participate in the forced displacement, besides that two thirds of the people over the age of 60 years, tend to live in countries where climatic disasters are more recurrent and which are characterized by in low- and middle-income regions, which are the ones that remain in spaces with infrastructure and precarious planification, in other words problems of habitability.

As a consequence, it results dominant consider restructuring of the meaning of Bioethics that goes beyond delimitation, breaks down barriers and includes all the elements that are involved in requirements for an ethical orientation that is related to health and life.

The consequences of climate change obligate us to generate new paradigms to supply better life conditions for populations and especially to those vulnerable groups such as the elderly. It is necessary an active attitude from citizens of the society, and different disciplines to encourage instruments of participation with an efficient and dignified intervention.

\section{REFERENCES}

Civic Design. (February, 2016). DESIGN / TERRITORY / COLLECTIVE INTELLIGENCE: Collaborative work of the Civic Design course group and the CivicWise people network [Blog Entry]. Retrieved November 11, 2019 from https://gumroad.com/I/NZnvG

Colagiuri, R., Boylan, S. \&Morrice, E. (2015). Priorities Research priorities for the prevention of NCDs and climate change: Delphi international survey. International Journal of Environmental Research and Public Health, 12(10), 12941-12957.

Departure Bush, V. (2005). The demographic transition and the aging process in Mexico. Papeles de Población, 11(45), 9-27.

Di Siena, D. (30 June 2015). What is Civic Design [Video Archive]. Retrieved November 11, 2019 from https://www.youtube.com/watch?v=h9W2fhjx87I

García J. (2017). Maslow's Pyramid: The Hierarchy of Human Needs. Retrieved October 14 from https://psicologiaymente.net/psicologia/piramide-demaslow.

HelpAge International. (2005). Climate change in an ageing world. Retrieved 12 September 2019, from http://www.helpagela.org/silo/files/el-cambioclimtico-en-un-mundo-que-envejece.pdf

INECC. (2019). National Atlas of Vulnerability to Climate Change. Retrieved September 12, 2019 from https://atlasvulnerabilidad.inecc.gob.mx/

INEGI. (2015). Intercensal Survey. Retrieved September 12, 2019, from http://www.beta.inegi.org.mx/proyectos/enchogares/especiales/intercensal/

Jacobs, J. (1961). Thedeath and lifeofgreat American cities. New York: Random House.

Lynch, K. (1960). The image of the city (3rd edition, 2nd tirada (2015) ed.). United States: Editorial Gustavo Gili.

MonoDestudio. (12 November 2015). The processes of participation as a city strategy. [Blog Entry]. Retrieved from http://monodestudio.es/procesosparticipativos/ 
Montaner, J. M. (1999). After the Modern Movement. Barcelona: Ed. Gustavo Pili.

Morales, M. A. (2010). Territorio sagrado: cuerpo humano y naturaleza en el pensamiento maya. Cuicuilco, 17(48), 279-298. Recuperado en 11 de noviembre de 2019, de http://www.scielo.org.mx/scielo.php?script=sci_arttext\&pid=S0185-16592010000100014\&lng=es\&tlng=es.

Morales, M. A. (2010). Sacred Territory: human body and nature in Mayan's thought. Cuicuilco, 17(48), 279-298. Retrieved November 11, 2019, from http://www.scielo.org.mx/scielo.php?script=sci_arttext\&pid=S0185-16592010000100014\&lng=es\&tlng=es.

PICC. (2014). Climate Change: Impacts, Adaptation, and Vulnerability; and Climate Change. Retrieved October 12 , 2019 from https://www.ipcc.ch/site/assets/uploads/2018/03/ar5_wgII_spm_es-1.pdf

Quiñones, L. (2019). UN. Retrieved October 21, 2019 from UN News: https://news.un.org/es/story/2019/10/1464591

Rapoport, A. (1972). (1st edition 1969, original title House form and Culture). Housing and Culture. Barcelona: Gustavo Gili.Partida Bush, V. (2005). La transición demográfica y el proceso de envejecimiento en México. Papeles de Población, 11(45), 9-27.

Sánchez-González, D. (2009). Environmental context and spatial experience of ageing in place: the case of Granada. Papeles de población, 15(60), 175-213. Retrieved 21 October 2019, from http://www.scielo.org.mx/scielo.php?script=sci_arttext\&pid=S1405-74252009000600008\&lng=es\&tlng=es.

Sarmiento, M. L. \&Fonti, D.O. (2014). Urban Bioethics: Challenges from an Emerging Field; United Nations Educational, Scientific and Cultural Organization. Red Latinoamericana y del Caribe de bioética; Revista Redbioética/UNESCO, 2(10), 110-118. Sánchez-González, D. (2009). Contexto ambiental y experiencia espacial de envejecer en el lugar: el caso de Granada. Papeles de población, 15(60), 175-213. Recuperado en 21 de octubre de 2019, de http://www.scielo.org.mx/scielo.php?script=sci_arttext\&pid=S1405-74252009000600008\&lng=es\&tlng=es.

Secretariat of Governance (2016) Migrants' Log, Migration Policy Unit Retrieved October 21, 2019 http://www.gobernacion.gob.mx/work/models/SEGOB/Resource/2767/1/images/11_Bit\%C3\%83\%C2\%A1cora_migratoria_Personas\%20migrantes\%20 por\%20causas\%20ambientales.pdf

Tajfel, H. (1983). Social psychology and social process. In J.R. Torregrosa and B. Sarabia (Dir.). Perspectives and contexts of social psychology. Barcelona: European Hispanic.

Tajfel, H. (1984). Human groups and social categories. Barcelona: Herder. (Original English edition 1981). 